\section{Choosing to Choose}

"For lack of getting out of it, I have chosen it."-Jean-Paul Sartre*

In "The Coming Contest" (College \& Research Libraries 54 [Nov. 1993]: 458-60), Ross Atkinson predicts that the needs of primary academic library users will eventually be met either by specialty scholarly publisher or by libraries. His editorial reflects an ongoing debate between alarmists, for whom he speaks, and equilibrists who believe that the status quo can be maintained in spite of environmental changes. This editorial, commenting on the future of the book and entitlement in academia, provides another alarmist view of the future of libraries.

The future of the book: The opening alarmist volley contends that libraries are probably going out of business, not so much because we should go out of business but because we are failing to understand our business well enough to maintain it. The equilibrists respond that F. W. Lancaster's prediction of a paperless society by the year 2000 certainly was inaccurate and that libraries will survive in the same way and for the same reasons. Elaborate and well-intentioned claims to the contrary, the equilibrists note, microform did not replace books, nor will the compact disc. The quintessential failed format (the betamax videocassette) is now virtually useless because players are no longer available. Few will argue that the book, a highly perfected form, will be entirely replaced. However, the convenience, flexibility, and stability of the book as an artifact will not necessarily save libraries.

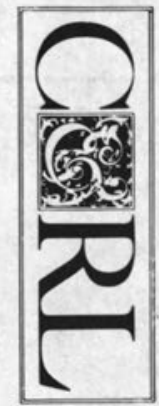

Further, the equilibrists continue, most scholars hate reading from the computer screen and regularly print documents over three pages long. Little money will be saved for colleges and universities if mass-produced pages of journal articles are printed for every user. Clearly, the alarmists note, this whole part of the revolution is awaiting the development of a book-sized, high-contrast, handheld, battery-powered computer for reading books and articles on disk. While many will miss the sensual aspects of the book-paper texture, ink smell, type aesthetics - many will rejoice in the ability to pack one reader and several disks in their vacation baggage. For those vacationing on remote beaches, longer-lasting batteries will be essential; such batteries are probably the current constraint in the development of this new high-tech toy. However, the average librarian's PC now contains the power of two or three 1970's room-sized computers. Without waiting for debate or decision, technology advances.

Working with a two- or three-generation time line to allow for complete resocialization, the alarmists predict that most materials, including archival files of handwritten working papers, will be available for retrieval via the Internet and its successors. Although the process of scanning will be lengthy and probably eventually incomplete, scholars in many disciplines will find that most of their information needs can be met electronically.

Entitlement: The equilibrists argue that libraries are sacred to the academy and will be maintained for sentiment if for no other reason. Dean of the University of Michigan School of Information and Li- 
brary Studies Dan E. Atkins recently referred to this status as an entitlement, a word undergoing rapid pejoration. Foundering academic institutions sense their own dangers and will make whatever cuts are necessary to retain what their administrators perceive as the essence. Increasingly, universities are outsourcing campus food services, bookstores, and photocopying to commercial enterprises. When an information vendor can promise academic administrators that students and faculty will be able to find most materials needed through a network in a more convenient mode available around the clock for a set fee (less than the entire budget of the library), how will the administrators respond? Some will recognize the possible emptiness of the promise and the probable escalation of the fees if the service is successful. As they did with bookstores, the alarmists note, others will see the reduced liability of having fewer employees with escalating benefits, less space accruing deferred maintenance, and declining need for support services.

Institutions in transition, and alarmists think colleges and universities may be just such institutions, sense their own dangers and will make decisions to ensure survival. Equilibrists believe that administrators will automatically recognize that the library is a part of the institution's educational mission. These administrators will ignore an opportunity for cost savings out of respect for past traditions.

For alarmists, economics is a driving force behind the creation and continuation of libraries. Neither the typical student nor the typical institution could afford to purchase all the books and articles necessary for the learning process. Sharing of institutionally owned materials among students and faculty, and among institutions themselves, allows broader and more affordable access as knowledge itself expands and publishing burgeons. Even the giant publishers and database vendors have only a small share of the total knowledge needed by a large university. While an institution with a limited curriculum, a nonresearch faculty, and no commitment to learning qua learning might be able to find a vendor to meet its students' primary needs, other institutions with broader configurations would have to deal with many, many information vendors and would still need to arrange for the use of additional resources just as even the largest research libraries currently must. Neither is the current environment nor in the forseeable future can one entity be envisioned as providing all information needed by users.

For these reasons, in some cases, economics could hold libraries in place if we focused, as Atkinson suggests, on high quality service. That would mean, however, that libraries would have to focus on measuring the quality of their services. Heeding instead of pettishly denigrating studies of reference accuracy, listening to complaints instead of excusing our services, and counting the costs of local cataloging variations from national standards and changing local practices would be required.

The equilibrists believe that they will receive a future analogous to their past; they need not exercise their freedom to choose. The alarmists believe that if we choose to understand our business, to serve our constituencies excellently, to know the interrelationships with the production and dissemination of knowledge, rather than to store books, then libraries might survive, albeit in much altered form. Some specific actions are needed:

- Librarians must be able to assess the effectiveness of their programs.

- Even though libraries have often ranked themselves as if they were warehouses, library associations must develop new, relevant standards.

- Librarians must communicate with administrators about the needs of the user community.

- Librarians must see themselves as sharing the environmental perils surrounding higher education.

- Librarians must understand and participate in the larger scholarly communications system.

- Librarians must listen to their users and change services appropriately. 
Librarians must focus on the nature of librarianship itself-not the buildings, the salaries, the status, the collections, the archives, but the essential serviceconnecting users with information needed regardless of format or ownership. Librarians must choose between changing to be relevant and nothingness.

GLORIANA ST. CLAIR

\section{REFERENCE}

* Jean-Paul Sartre, Being and Nothingness, trans. Hazel Barnes (New York: The Citadel Press, 1969), 530.

\section{IN FORTHCOMING ISSUES OF \\ COLLEGE \& RESEARCH LIBRARIES}

A Model for Reviewing Academic Branch Libraries Based on ACRL Guidelines and Standards

Olivia Madison, Sally Fry, and David Gregory

Organizational Commitment of Professional Employees in Union and

Nonunion Research Libraries

Tina Maragou Hovekamp

Making Reference Services Work

David. W. Lewis

Nontraditional Students and the Academic Library: A Study of Student Opinion, Preferences, and Library Use Behaviors

Carol Hammond

Evaluating the Effectiveness of a Concept-based Computer Tutorial for OPAC Users Joan Cherry, Weijing Yuan, and Marshall Clinton 
Struggling to survive in the face of severe federal funding cutbacks, more and more Native American tribes have turned to gambling to keep their reservations going. With some reservation casinos grossing millions of dollars a year, the plan has seemed successful. But some state legislators

\section{In their LATESt Fight With the government, Native Americans \\ HAVE RESORTED TO SOME POWERFUL NEW WEAPONS.}

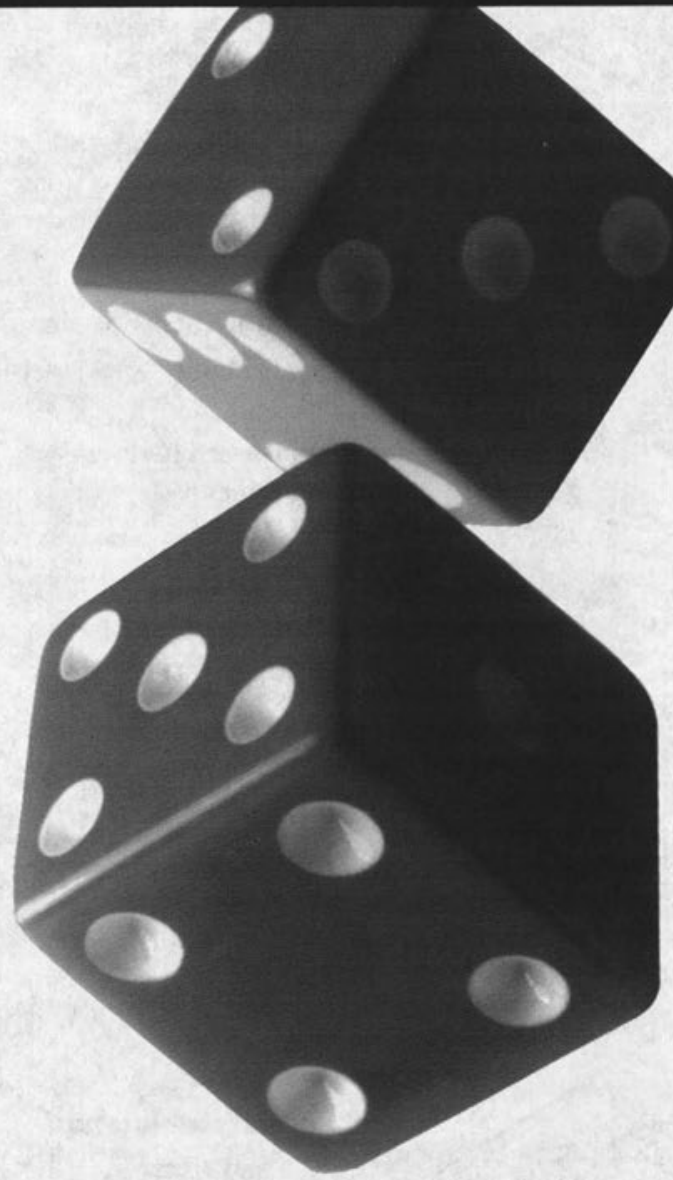

say it's bad medicine. And so the conflict between the cowboys and the Indians continues...

Legislation on Native American casinos is an issue that packs significant national import.

Which is why it's one of the thousands of subjects covered by PAIS International.

\section{Coverage that crosses all borders} From Congressional legislation to banking regulations, PAIS International provides a unique breadth of coverage on state, interstate, national and international levels. In all, PAIS online and CD-ROM indexes give you access to over 350,000 journal articles, government documents, statistical directories, monographs, conference reports and more. And to provide an unrivaled international outlook, PAIS references literature published around the world in English, French, German, Italian, Spanish and Portuguese.

So the next time you're shooting for hard-tofind data, don't gamble. Use PAIS.

Public Affoirs Information Service, ${ }^{\otimes} \mathrm{nc}$.

521 West 43rd Street, New York, NY 10036-4396 800-288-PAIS, $212-736-6629$ (in NYC) Fox: 212-643-2848

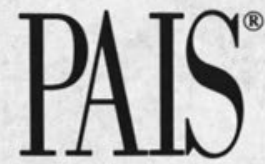

No one looks at the world like PAIS

In Print: PAIS INTERNATIONAL IN PRINT ${ }^{\circ}$ - PAIS SUBIECT HEADINGS Online Through: DATA-STAR • DIALOG • OCLC • RLG On CD-ROM: PAIS ON CD-ROM. PAIS INTERNATIONAL ON SIVIERPLATTER On Magnetic Tape: CONTACT PAIS FOR INFORMATION 


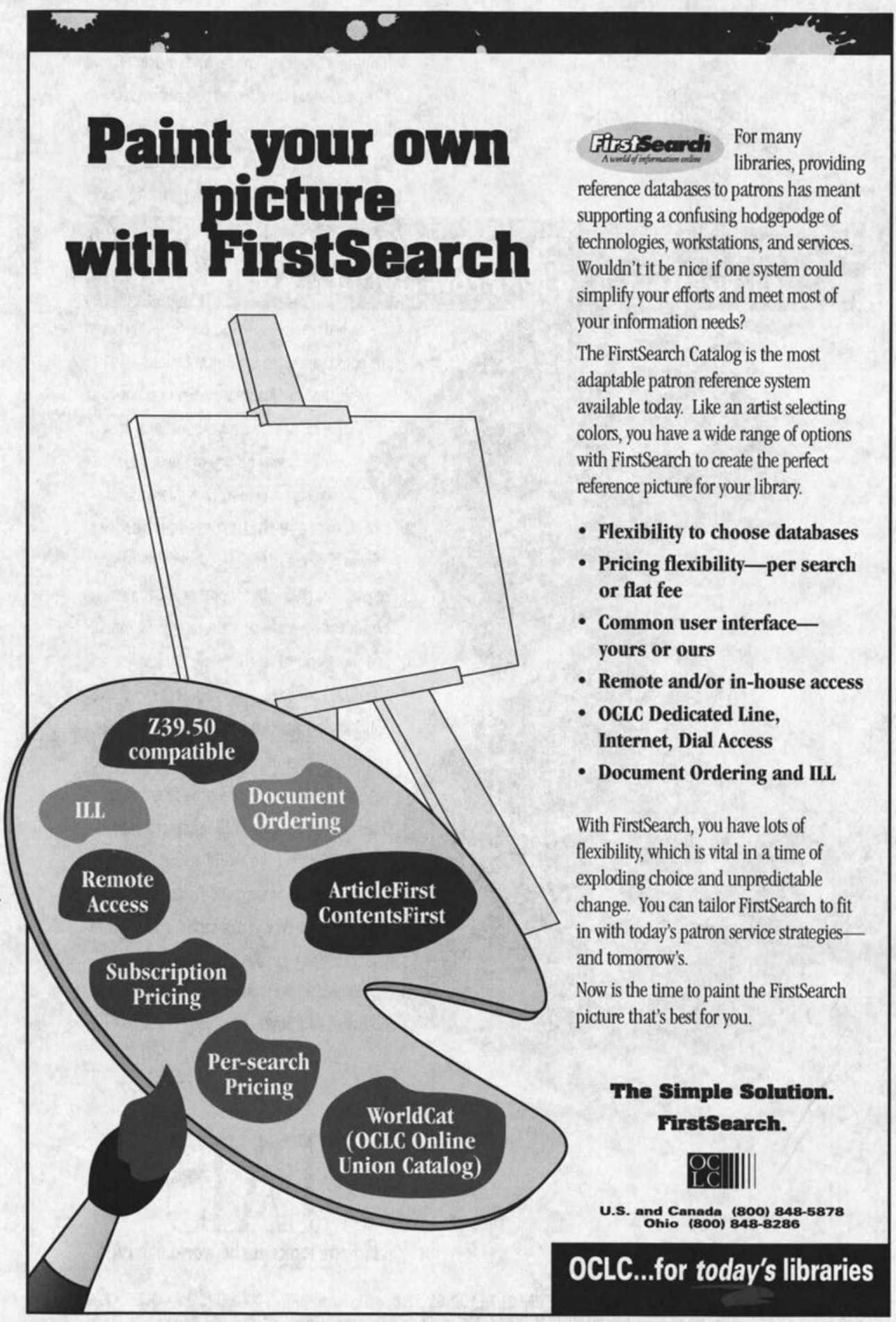

